DOI 10.37882/2223-2982.2021.09-2.21

\title{
ДИДАКТИЧЕСКИЙ ПОТЕНЦИАЛ ДИСЦИПЛИН ГУМАНИТАРНОГО ЦИКЛА В РАЗВИТИИ РЕФЛЕКСИВНОЙ КОМПЕТЕНТНОСТИ (НА ПРИМЕРЕ ПЕДАГОГИЧЕСКОГО ВУЗА)
}

\section{THE DIDACTIC POTENTIAL OF THE DISCIPLINES OF THE HUMANITARIAN CYCLE IN THE DEVELOPMENT OF REFLEXIVE COMPETENCE (ON THE EXAMPLE OF A PEDAGOGICAL UNIVERSITY)}

\section{Skopa}

Summary: The article examines the role of the disciplines of the humanitarian cycle in the development of reflexive competence. Preparation for the implementation of professional pedagogical activity involves the formation of skills to correlate their professional actions with the capabilities and individual characteristics of students, to predict the consequences of their actions in practical pedagogical activity. The relevance in the formation of sociocultural reflection is explained by the challenges of realities and circumstances, where a novice teacher himself needs to holistically understand and make a conscious choice, and subsequently convey ideas, views, views to the younger generation. Reflexive competence is presented as a complex formation consisting of various types of reflection. Humanitarian training lays down values that allow for sociocultural reflection.

Keywords: humanitarian disciplines, competence, social reflection students, higher education.

\author{
Скопа Виталий Александрович \\ Д.и.н., профессор, Алтайский государственный \\ педагогический университет, г. Барнаул \\ sverhtitan@rambler.ru
}

Аннотация: В статье рассматривается роль дисциплин гуманитарного цикла в развитии рефлексивной компетентности. Подготовка к осуществлению профессиональной педагогической деятельности предполагает формирование умений соотносить свои профессиональные действия с возможностями и индивидуальными особенностями учащихся, прогнозировать последствия своих действий в практической педагогической деятельности. Актуальность в формировании социокультурной рефлексии объясняется вызовами реалий и обстоятельств, где начинающему педагогу необходимо самому целостно понимать и делать осознанный выбор, а в последствии доносить идеи, взгляды, воззрения до подрастающего поколения. Рефлексивная компетентность представлена как сложное образование, состоящее из различных видов рефлексии. Гуманитарная подготовка закладывает ценностные ориентиры, позволяющие осуществлять социокультурную рефлексию.

Ключевые слова: гуманитарные дисциплины, компетентность, социальная рефлексия, студенты, высшее образование.
B процессе развития современного общества образование все больше ориентируется на утверждение личностного активного начала в человеке. Это проявляется не только в том, что личность не только владеет определенной суммой знаний и подготовлена к компетентному выполнению профессиональной деятельности, но и способна к дальнейшему самосовершенствованию, саморазвитию и самореализации.

Тенденция, связанная с приоритетом личностного, активного начала, предполагает ориентацию студентов в сфере знаний о себе, о своих образовательных потребностях, возможностях и способностях, знаний о своем личном потенциале и возможных маршрутах его реализации и развития в процессе профессионального образования. Подготовка к осуществлению профессиональной педагогической деятельности предполагает также и формирование умений соотносить свои профессиональные действия с возможностями и индивидуальны- ми особенностями учащихся, прогнозировать последствия своих действий в практической педагогической деятельности.

Важной составляющей профессиональной подготовки современного учителя является обеспечение его способности проявлять себя как сформированную социально зрелую личность, способную выполнять свои функциональные обязанности не только как педагогпредметник, но и осуществлять рефлексию контроверсионных социальных процессов, которые происходят как в России, так и мире в целом. Исходя из этого объясняется необходимость формирования социокультурной рефлексии у студента высшего педагогического учебного заведения. К тому же, еще одной предпосылкой обращения к исследованию дидактического потенциала гуманитарных дисциплин является то, что на сегодняшний день их роль и значение существенно принижается (сокращается) как дефиниций, формирующих общекуль- 
турные компетенции [3].

Актуальность в формировании социокультурной рефлексии во многом объясняется вызовами реалий и обстоятельств, где начинающему педагогу необходимо самому целостно понимать и делать осознанный выбор, а в последствии доносить идеи, взгляды, воззрения до подрастающего поколения, что во многом, в последствии, является базисом их мировоззренческого развития.

Рефлексивная компетентность, по определению С.Ю. Степанова, - это «профессиональное качество личности, позволяющее наиболее эффективно и адекватно осуществлять рефлексивные процессы, реализацию рефлексивной способности, что обеспечивает развитие и саморазвитие, способствует творческому подходу в профессиональной деятельности, достижению ее максимальной эффективности и результативности» [13]. В рефлексивной психологии рефлексивная компетентность представлена как сложное образование, состоящее из различных видов рефлексии: кооперативной, построенной на знании ролевой структуры и позиционной организации коллективного взаимодействия; коммуникативной, основанной на представлениях о внутреннем мире другого человека и причинах его поступков; личностной, в основе которой лежат поступки, поведение и образы собственного «Я»; интеллектуальной, которая оперирует знаниями об объекте и способах действия с ним [14].

Современная историография заявленной проблемы весьма разнообразна как в части теоретических трактовок, так и методологических подходах, и воззрениях. Новые взгляды и стратегии в организации образовательной деятельности в высшей школе в контексте реализации положений Болонского процесса изучали И. Зязюн, Н. Кузьмина; проблему профессионально-педагогического становления преподавателя высшей школы, который формирует личность будущего учителя актуализировали В. Галузинский, В. Гончаров, С. Григорьев. Отдельные аспекты подготовки педагогических кадров, проблемы педагогического мастерства и становление преподавателей высшей школы представлены в работах В. Бабкина, Е. Барбина, В. Загвязинского, М. Иванова, В. Ковалева, В. Антипова, Н. Кузьмина, Е. Вознесенской, Ж. Де Лансер.

В концепции непрерывного педагогического образования отмечается, что системное совершенствование подготовки и повышения квалификации педагогических работников обусловлено изменением роли человека в современном мире. Современному специалисту выдвигаются новые требования в контексте трансформации культурных, нравственных, духовных, общественных, экономических, политических установок, а также много- численными вызовами глобального, европейского, национального, регионального и местного уровней [1]. Система подготовки педагогических кадров является фундаментальной основой для человека, имеющего отношение к таким процессам как социализация, обучение или воспитание. Квалификационный уровень образования позволяет определять степень эффективности решения профессиональных задач воспитателя, учителя, преподавателя высшего учебного заведения и системы дополнительного образования детей и взрослых. Подготовка и повышение квалификации научно-педагогических и педагогических работников рассматривается в этом контексте как важная предпосылка, обеспечивающая проведение модернизации образования на основе осмысления национального и зарубежного опыта [9].

Ключевой задачей подготовки учителей является формирование их профессиональной компетентности [6]. Развитие профессиональных умений будущих учителей является комплексным процессом, который осуществляется в течение всего обучения и включает в себя социально-гуманитарную, психолого-педагогическую, профессиональную и практическую подготовку.

Социально-гуманитарная подготовка предусматривает углубление и профессионализацию знаний исторического, философского, правоведческого, культурологического и других направлений. Именно данный раздел закладывает ценностные ориентиры, позволяющие осуществлять социокультурную рефлексию.

Содержание психолого-педагогической подготовки определяется такими учебными дисциплинами как педагогика (дидактика, теория воспитания, история педагогики и т.д.) и психология (общая психология, возрастная психология, педагогическая психология и др.) [4]. В подготовке педагогических кадров данный модуль является основополагающим и принципиальным, поскольку профессионально идентифицирует будущего учителя как «профессионала-индивида».

Профессиональная подготовка предполагает формирование у студентов теоретических знаний по базовым учебным дисциплинам специальности.

Практическая подготовка происходит посредством учебных и профессиональных (педагогических) практик [8].

Исходя из теории и практики педагогического процесса, Ю.К. Бабанский, Н.В. Кузьмина, Ю.Н. Кулюткин, В.А. Сластенин считают рефлексивность одним из профессионально значимых личностных качеств любого педагога-практика. В основе рефлексии педагога лежит педагогическая рефлексия, которая позволяет применять такие характеристики рефлексии, как осмысление 
и осознание форм и предпосылок человеческого мышления, предметное рассмотрение знания, критический анализ его содержания и методов познания, самопознание применительно к педагогической деятельности. Развитие рефлексивной позиции учителя выступает одним из условий его психолого-педагогической компетентности, так как позволяет учителю ставить себя в позицию ученика, видеть и оценивать его трудности его глазами, прогнозировать необходимые и значимые для него формы помощи, дает возможность оценивать эффективность обратной связи [6].

В современной литературе оформление учебного процесса трактуется с одной стороны, как обучение через информацию, с другой - обучение через деятельность. При изучении гуманитарных дисциплин мы можем применять различные формы и методы обучения. Важно заметить, что проблема методов обучения всегда занимала одно из ведущих мест в отечественной педагогике, поскольку именно методы позволяют воплотить стратегическую цель общества - формирование всесторонне и гармонично развитой личности, где роль гуманитарных дисциплин основополагающая [7, 12].

Дидактическую классификацию методов с учетом специфики целей и содержания обучения распространил И. Лернер [5]. По его модели: педагог ставит перед собой дидактическую цель; деятельность и средства учителя приводят к появлению цели у учащихся; действия ученика определяют объективные внутренние процессы, которые ведут его к достижению поставленной цели [5].

Основной целью образовательного процесса, исходя из теоретических основ педагогической науки, является создание организованного, предсказуемого и целенаправленного педагогического влияния на формирование личности с заданными качествами. Развитие критического мышления происходит в процессе познавательной деятельности, где результатом является определенные трансформации психического состояния студента [10]. Это прослеживается в достижении конкретного уровня развития, воспитанности, знаний, умений, навыков.

В данном научном рассуждении важным является определение профессиональной рефлексии, которая заключается в соотнесении себя, возможностей своего «Я» с тем, что требует выбранная профессия, а также с существующими о ней представлениями. Данные представления имеют свойства развития и способствуют человеку сформулировать полученные результаты, предвидеть цели дальнейшей работы, осуществлять коррекцию своего профессионального пути [4]. Существенным дополнение к пониманию заявленной проблемы является привлечение зарубежных концепций. Так Дж. Дьюи уста- новил связь между рефлексивным мышлением и процессом обучения. Шон Д. считает, что рефлексия в процессе деятельности происходит во время преподавания в форме спонтанной реакции учителя на этот процесс и на проблемы, которые возникают в результате интеракции педагога со студентами. Такая рефлексия происходит в реальном времени и требует быстрого понимания того, что происходит, и безотлагательного решения проблемы [8].

Основными факторами, способствующими формированию социальной рефлексии будущих учителей, является изучение гуманитарных дисциплин. Современная система образования позволяет комплексно и всесторонне подходить к изучению предметов данного блока. Отдельное внимание заслуживают педагогические технологии, которые, с учетом развития теории и практики существенно разнообразились. Наблюдения, систематические собеседования, опросы и регулярное анкетирование студентов, будущих учителей показывают, что с каждым учебным годом значительно возрастает интерес студентов к тем образовательным технологиям, которые внедряются в практику работы школ и высших педагогических заведений. Новые технологические приемы позволяют добиваться высоких результатов в части знаниевого компонента у студентов по дисциплинам гуманитарного цикла, что является важнейшей основой для формирования социокультурной рефлексии. К тому же, такие предметы как история, философия, культурология формируют гражданско-нравственную позицию, умение аргументировано подходить к той или иной точке зрения, апеллируя сформированными знаниями.

Для формирования у будущих учителей вариативности мышления, способности реализовывать прогностическую, исследовательскую, управленческую, дидактико-методическую и другие производственные функции необходимо выполнение следующих условий:

- использовать совокупность методов обучения, в том числе осуществлять рефлексию образовательной и самообразовательной деятельности на интеграционной основе;

- обобщать результаты и прогнозировать социально значимую деятельность;

- применять различные средства обучения: новые информационные технологии; интенсифицировать и активизировать формы и методы обучения и самообучения; заложить реализацию задачного подхода в обучении; индивидуализировать научно-исследовательские задания; применить средства иноязычного общения [11].

Формирование социальной рефлексии в процессе профессиональной подготовки и стратегической направленности на инновационный тип деятельности будущей профессии реализуется через применение 
соответствующих форм организации обучения, среди которых можно выделить самостоятельную работу и формы организации учебной деятельности в процессе изучения системы педагогических дисциплин, которые имеют особенно высокий потенциал по развитию социальной рефлексии студента. Данный подход соответствует современным требованиям и способствует осознанному саморазвитию учителя.

Таким образом, можно отметить, что важной составляющей профессиональной подготовки современного учителя является обеспечение его способности проявлять себя как сформированную социально зрелую личность, которая способна выполнять свои функциональные обязанности. В процессе развития социальной рефлексии студента важно подчеркнуть роль гуманитарных дисциплин и организационных форм обучения, в совокупности, в наибольшей степени отвечающих за развитие социальной рефлексии будущего учителя и непосредственно влияющих на общую эффективность учебной деятельности, соответственно, формируя социальную рефлексию студента.

\section{ЛИТЕРАТУРА}

1. Беспалько В.П. Педагогика и прогрессивные технологии обучения. М., 1995. 490 с.

2. Вербицкий А.А. Активное обучение в высшей школе: контекстный подход. М., 1991. 207 с.

3. Данилов Д.А., Корнилова А.Г. Индивидуальная подготовка студента к профессионально-педагогической деятельности. Якутск: ЯНЦ СО РАО; ЯГУ, 2001. $48 \mathrm{c}$.

4. Левина М.М. Технологии профессионального педагогического образования. М., 2001. 272 с.

5. Лернер И.Я. Дидактические основы методов обучения. М., 1990. 186 с.

6. Лукьянова М.И. Психолого-педагогическая компетентность учителя: Диагностика и развитие. М., 2004. 284 с.

7. Малыхин А.В. Формирование рефлексивной компетентности студентов в образовательном процессе высшей школы. М.,2015. 274 с.

8. Опалюк Т.Л. Активно используемые формы организации учебной деятельности в педагогических университетах в процессе формирования социальной рефлексии будущего учителя // Интернаука. 2017. № 17 (21).

9. Педагогика в вузе как учебный предмет: Сб. научных трудов. СПб.: Изд-во РГПУ им. А.И. Герцена, 2001. 192 с.

10. Сластенин В.А. Формирование личности учителя советской школы в процессе профессиональной подготовки. М., 1976. 160 с.

11. Шиянов Е.Н. Гуманизация профессионального становления педагога // Педагогика. 1992. № 9. С. 80-84.

12. Якиманская И.С. Личностно-ориентированное обучение в современной школе. М., 2000. 192 с.

13. Степанов С.Ю., Похмелкина Г.Ф. Принципы рефлексивной психологии педагогического творчества // Вопросы психологии. 1991. № 5. С. $35-38$.

14. Сластенин В.А. Рефлексивная культура и профессионализм учителя // Педагогическое образование и наука. 2005. № 3. С. 37-43.

( ) Скопа Виталий Александрович (sverhtitan@rambler.ru). 